\title{
PATTERN OF OCULAR ACCIDENTS IN CEYLON*
}

\author{
BY \\ LLOYD WEEREKOON \\ Colombo Eye Hospital, Colombo, Ceylon
}

CEYLON is gradually turning from agriculture to industry, so that an analysis of the pattern of ocular accidents in pre-industrialized Ceylon may be of some interest. This paper is based on a series of 261 accidents involving the eye that were seen at the Ophthalmic Department of a large General Hospital in the hill country over the last 4 years, and may be taken as an index of the type of accident to be found anywhere in the island.

There are, of course, exceptions due to local patterns of industry. In the south, the emphasis would be on the lime, coir, pottery, and mat-weaving industries, with rubber and coconut cultivation as major industries. In the Central Provinces, the concentration would be on tea and rice, with Dumbara mats, silver and brass ware, lacquer work, and brick-making as cottage industries, though rubber and coconut are also found. Further north, fireworks accidents might perhaps top the list, though cement is the major industry there, with mat-weaving, textiles, and footwear as subsidiaries. These local undertakings do not appreciably alter the general pattern, but merely provide a local bias to the general picture.

\section{Type of Accident (Tables I and II)}

In a country where agriculture is the major pursuit, it is to be expected that agricultural hazards occupy first place with 99 cases ( 34 per cent.). Of these, 73 cases were from the tea plantations, the accident being caused by the tea branch striking the eye while the patient was pruning, weeding, or manuring the land. Actual tea-plucking is apparently without serious hazard. It should be noted, moreover, that tea branches form a major cause of industrial blindness in this series, being responsible for 32 per cent. (Table IIA, p. 447). Of the 34 patients who lost vision

TABLE I

GENERAL CLASSIFICATION OF 261 ACCIDENTS (221 MEN, 12 WOMEN, AND 28 CHILDREN)

\begin{tabular}{l|c}
\multicolumn{1}{c|}{ Class } & No. of Cases \\
\hline 1. Agricultural & 99 \\
2. Industrial & 62 \\
3. Chemical (Burns) & 26 \\
4. Home and School & 28 \\
5. Miscellaneous & 43 \\
6. Unspecified & 3 \\
\hline Total & 261 \\
\hline
\end{tabular}

* Received for publication August 8, 1963. 
TABLE II

DETAILED ANALYSIS OF CLASSES SHOWN IN TABLE I

\begin{tabular}{|c|c|c|c|}
\hline Class & Cause of Accident & No. of Cases & Total \\
\hline 1. Agricultural & $\begin{array}{l}\text { Tea branch } \\
\text { Rubber strip } \\
\text { Cocoa leaf } \\
\text { Coffee branch } \\
\text { Grass blade } \\
\text { Paddy stalk }\end{array}$ & $\begin{array}{r}73 \text { (Table IIA) } \\
6 \\
1 \\
1 \\
17 \\
1\end{array}$ & 99 \\
\hline 2. Industrial & $\begin{array}{l}\text { Blasting } \\
\text { Welding } \\
\text { Stone-cutting } \\
\text { Carpentry }\end{array}$ & $\begin{array}{r}30 \text { (Table IIB) } \\
29 \text { (Table IIC) } \\
1\end{array}$ & 62 \\
\hline 3. Chemical (Burns) & $\begin{array}{l}\text { Cement } \\
\text { Lime } \\
\text { Acetic acid } \\
\text { Solignum } \\
\text { Fertilizer } \\
\text { Acid } \\
\text { Fungicide } \\
\text { Insecticide } \\
\text { "Perenox" } \\
\text { "Antimucin" } \\
\text { Boiling water }\end{array}$ & $\begin{array}{l}2 \\
6 \\
1 \\
1 \\
9 \\
2 \\
1 \\
1 \\
1 \\
1 \\
1\end{array}$ & 26 \\
\hline 4. Home and School & $\begin{array}{l}\text { Scissors } \\
\text { Pen } \\
\text { Pencil } \\
\text { Finger } \\
\text { Boiling water } \\
\text { Burn } \\
\text { Splinter } \\
\text { Stone } \\
\text { Orange } \\
\text { Lime } \\
\text { Fall } \\
\text { Stick } \\
\text { Areca-nut } \\
\text { Football } \\
\text { Hockey stick } \\
\text { Golf club } \\
\text { Cricket ball } \\
\text { Firework }\end{array}$ & $\begin{array}{l}2 \\
1 \\
2 \\
1 \\
1 \\
1 \\
1 \\
1 \\
1 \\
2 \\
3 \\
6 \\
1 \\
1 \\
1 \\
1 \\
1 \\
1\end{array}$ & 28 \\
\hline 5. Miscellaneous & $\begin{array}{l}\text { Single foreign body } \\
\text { Spark } \\
\text { Stick } \\
\text { Wood splinter } \\
\text { Fall } \\
\text { Road accident } \\
\text { Wire } \\
\text { Mango latex } \\
\text { Sand } \\
\text { Iron } \\
\text { Bamboo sliver } \\
\text { Tree branch } \\
\text { Wooden bar } \\
\text { Stores } \\
\text { Factory } \\
\text { Earth and rubble } \\
\text { Grit } \\
\text { Knitting needle } \\
\text { Firewood } \\
\text { Confectionery }\end{array}$ & $\begin{array}{l}7 \\
2 \\
8 \\
3 \\
5 \\
1 \\
2 \\
1 \\
1 \\
1 \\
1 \\
1 \\
1 \\
1 \\
1 \\
2 \\
1 \\
1 \\
2 \\
1\end{array}$ & 43 \\
\hline
\end{tabular}


permanently, 29 had corneal ulceration with or without hypopyon, four had a cut cornea or sclera, and one had a detached retina.

Minor industrial accidents accounted for 62 cases, of which rock-blasting (a common occupation in the hill country with its rocky terrain) and stone-cutting numbered 30 and 29 respectively. Of the thirty cases of blasting accident, 25 (83 per cent.) suffered permanent and total loss of vision of one or both eyes. (Four of these lost both eyes.) This makes rock-blasting the most dangerous occupation to-day, for though it accounts for only 9 per cent. of all accidents to the eye, it is responsible for 23 per cent. of industrial blindness in our series. Of the thirty cases of rock-blasting, fifteen had penetrating injuries, with or without panophthalmitis and/or traumatic cataract, six had ruptured globes, eight deeply-embedded foreign bodies, and one a cut sclera (Table IIB, opposite).

Stone-cutting accounted for 29 cases, 11 per cent. of the total. Of these, 23 occurred in stone-cutters, whose occupation is parallel to rock-blasting. The six other cases included a carpenter who had time to stand and stare at a fellow-worker who was cutting stone; a garage mechanic who had a grind-stone fragment hit him in the eye causing a ruptured globe; a third was a mason; a fourth was a child (who lost his eye from a hypopyon ulcer); the fifth a bus driver; and the sixth a railway spannerman (Table IIC). Sixteen patients ( 55 per cent.) lost vision permanently from corneal ulceration (8), cut cornea (1), intra-ocular foreign body (1), retrobulbar foreign body (1), ruptured globe (1), panophthalmitis (2), and dislocated lens (2). Ulceration of the cornea with or without hypopyon, and its sequel of corneal scarring (nebulae or maculae) was the common end-result of this type of accident. Stone-cutting thus becomes responsible for 15 per cent. of cases of industrial blindness in this series (Table IIC, opposite).

Another serious type of accident is that caused by a blade of grass when the patient is stooping to cut grass with a sickle. There were seventeen such cases, and in all save five the eye was totally lost from corneal ulcer (7), panophthalmitis (3), or keratitis (2). This type of accident was responsible for 11.3 per cent. of industrial blindness.

Chemical burns accounted for 26 cases (10 per cent.). Of these, seven cases ended in permanent and total loss of vision (i.e. 6.6 per cent. of blindness). Oddly enough, only one of six cases of lime burn resulted in total visual loss, and this was a very severe one with vascularization of the cornea and symblepharon (Table II).

\section{Children}

28 of the patients (10 per cent.) were children (Table III, overleaf). Accidents occurred both at home and at school (Table II). Permanent loss of vision occurred in six cases only: cut cornea (2), optic atrophy after a fall (1), hypopyon following injury with a stone (1), and macular holes that appeared in older school boys (2), one after a football had struck the eye and the other after an injury with a golf club, this last in a youth 19 years of age. Football, cricket, hockey and golf were all represented by one accident each-hardly large enough to discourage these games. Accidents in children accounted for 5.6 per cent. of blindness in this series. In the West the commonest type of injury in children is the cut cornea caused by a bow and arrow accident or an intra-ocular air gun pellet. 
TABLE IIA

DETAILS OF 73 TEA BRANCH INJURIES (32 PER CENT. OF ALL CASES OF INDUSTRIAL BLINDNESS)

\begin{tabular}{l|c|c}
\hline \multicolumn{1}{c|}{ Lesion } & No. of Cases & Total \\
\hline $\begin{array}{l}\text { Conjunctival abrasion } \\
\text { Contusion } \\
\text { Subconjunctival haemorrhage } \\
\text { Corneal abrasion }\end{array}$ & 39 & 73 (34 with total loss of vision) \\
\hline Ulceration of cornea (with/without hypopyon) & 29 & \\
\hline Retinal detachment & 1 & \\
\hline Cut cornea/sclera & 4 & \\
\hline
\end{tabular}

TABLE IIB

DETAILS OF 30 BLASTING ACCIDENTS TO LOADERS OF DYNAMITE (23 PER CENT. OF ALL INDUSTRIAL BLINDNESS)

\begin{tabular}{l|r|l|r}
\hline \multicolumn{1}{c|}{ Lesion } & No. of Cases & Visual Loss & No. of Cases \\
\hline Ruptured globe & 6 & Total Both eyes & 4 \\
Penetrating foreign body & 15 & Partial eye & 21 \\
Multiple foreign bodies (non-penetrating) & 8 & No loss & 3 \\
Cut sclera & 1 & Total & 30 \\
\hline \multicolumn{1}{c|}{ Total } & 30 & & 30 \\
\hline
\end{tabular}

TABLE IIC

DETAILS OF 29 INJURIES CAUSED BY STONE FRAGMENTS (15 PER CENT. OF ALL INDUSTRIAL BLINDNESS)

\begin{tabular}{|c|c|c|c|c|c|}
\hline Lesion & $\begin{array}{l}\text { No. of } \\
\text { Cases }\end{array}$ & Occupation & $\begin{array}{l}\text { No. of } \\
\text { Cases }\end{array}$ & $\begin{array}{c}\text { Visual } \\
\text { Loss }\end{array}$ & $\begin{array}{l}\text { No. of } \\
\text { Cases }\end{array}$ \\
\hline $\begin{array}{l}\text { Corneal ulceration/perforation } \\
\text { Hypopyon ulcer } \\
\text { Corneal abrasion/nebula } \\
\text { Corneal macula } \\
\text { Dislocated lens } \\
\text { Conjunctival abrasion } \\
\text { Episcleral nodule } \\
\text { Panophthalmitis } \\
\text { Subconjunctival haemorrhage } \\
\text { Intra-ocular foreign body } \\
\text { Retrobulbar foreign body } \\
\text { Cut cornea } \\
\text { Ruptured globe }\end{array}$ & $\begin{array}{l}2 \\
6 \\
7 \\
2 \\
2 \\
2 \\
1 \\
2 \\
1 \\
1 \\
1 \\
1 \\
1\end{array}$ & $\begin{array}{l}\text { Stone cutter } \\
\text { Mason } \\
\text { Carpenter } \\
\text { Garage mechanic } \\
\text { Children } \\
\text { Spannerman } \\
\text { Bus driver }\end{array}$ & $\begin{array}{r}23 \\
1 \\
1 \\
1 \\
1 \\
1 \\
1\end{array}$ & $\begin{array}{l}\text { Total } \\
\text { Partial } \\
\text { No Loss }\end{array}$ & $\begin{array}{r}16 \\
2 \\
11\end{array}$ \\
\hline Total & 29 & Total & 29 & Total & 29 \\
\hline
\end{tabular}


TABLE III

DETAILS OF 28 ACCIDENTS TO CHILDREN (5 PER CENT. OF ALL INDUSTRIAL BLINDNESS)

\begin{tabular}{l|c|c|c}
\hline \multicolumn{1}{c|}{ Lesion } & No. of Cases & Visual Loss & No. of Cases \\
\hline Cut cornea & 2 & Total & 6 \\
Hypopyon ulcer & 1 & Partial & 20 \\
Optic atrophy & 1 & & \\
Macula hole & 2 & & \\
Macular oedema & 1 & & \\
Ecchymosis of lid & 1 & & \\
Corneal burn & 1 & Total & 28 \\
\hline Trivial & 28 & & \\
\hline Total & &
\end{tabular}

Nature of Injury (Table IV)

The commonest minor injury was the corneal abrasion (34 cases) with or without a nebula corneae as an end-result. There were 27 conjunctival abrasions, 44 cases of corneal ulceration with or without perforation and hypopyon keratitis with or without ulceration, eight multiple deeply-embedded foreign bodies and seven single foreign bodies (a total of fifteen cases of penetrating foreign bodies). There were also nine ruptured globes and ten cases of cut cornea or sclera.

Internal injuries without perforation included hyphaema (2), vitreous haemorrhage (1), dislocated lens (2), retinal detachment (1), macular hole (3), optic atrophy (2), and hemianopia after a road accident (1).

In Great Britain the commonest ocular injury in the adult is the single foreign body. Classified broadly, there were thus 37 penetrating and 224 non-penetrating injuries.

TABLE IV

NATURE OF INJURY IN 261 CASES

\begin{tabular}{|c|c|c|c|c|c|c|c|}
\hline \multicolumn{6}{|c|}{ Non-Penetrating (224) } & \multirow{3}{*}{\multicolumn{2}{|c|}{ Penetrating (37) }} \\
\hline \multicolumn{4}{|c|}{ External (204) } & \multirow{2}{*}{\multicolumn{2}{|c|}{$\begin{array}{c}\text { Internal (20) } \\
\text { (without perforation) }\end{array}$}} & & \\
\hline Conjunctival (52) & \multicolumn{2}{|l|}{ Corneal (142) } & Adnexal (10) & & & & \\
\hline $\begin{array}{lr}\text { Haemorrhage } & 10 \\
\text { Hyperaemia } & 7 \\
\text { Abrasion } & 27 \\
\text { Epithelial nodule } & 4 \\
\text { Contusion } & 4\end{array}$ & $\begin{array}{l}\text { Abrasion } \\
\text { Ulceration } \\
\text { Keratitis } \\
\text { Maculae } \\
\text { Multiple foreign bodies } \\
\text { Single foreign body } \\
\text { Abscess } \\
\text { Burn }\end{array}$ & $\begin{array}{r}34 \\
44 \\
13 \\
11 \\
8 \\
7 \\
2 \\
23\end{array}$ & $\left.\begin{array}{l}\text { Eyebrow } \\
\text { Eyelid } \\
\text { Lacrimal sac } 3\end{array}\right\} \begin{array}{l}7 \\
3\end{array}$ & $\begin{array}{l}\text { Panophthalmitis } \\
\text { Detachment } \\
\text { Dislocated lens } \\
\text { Vitreous haemorrhage } \\
\text { Hyphaema } \\
\text { Optic atrophy } \\
\text { Hemianopia } \\
\text { Macular hole }\end{array}$ & $\begin{array}{l}7 \\
1 \\
2 \\
1 \\
1 \\
2 \\
2 \\
1 \\
4\end{array}$ & $\begin{array}{l}\text { Cut cornea/sclera } \\
\text { Intra-ocular foreign body } \\
\text { Penetrating foreign body } \\
\text { Retrobulbar foreign body } \\
\text { Traumatic cataract } \\
\text { Ruptured globe }\end{array}$ & $\begin{array}{r}10 \\
1 \\
15 \\
1 \\
1 \\
9\end{array}$ \\
\hline
\end{tabular}

\section{Occupation of Patient (Table V, opposite)}

The occupation of the individual was related to the type of accident in most cases. The exceptions have already been mentioned. The greatest number of cases occurred amongst the tea-estate labourers. The second and third commonest came far behind with 29 cases amongst loaders of dynamite (blasting accidents), and 24 among stonecutters. This is to be expected in an area that is predominantly occupied by teaplanting, with dynamiting and stone-cutting as secondary occupations in the rocky hill country. 
TABLE V

OCCUPATIONS OF 261 CASES

\begin{tabular}{l|c} 
Occupation & No. of Cases \\
\hline Tea-estate labourer & 119 \\
Loader (of dynamite) & 29 \\
Stone-cutter/mason & 24 \\
Rubber-estate labourer & 8 \\
Unskilled labourer & 6 \\
Garage mechanic & 4 \\
Machinist & 2 \\
Merchant & 2 \\
Welder & 2 \\
Cultivator & 2 \\
Factory hand & 1 \\
Fireman (Railway) & 1 \\
Tinker & 1 \\
Carpenter & 1 \\
Estate superintendent & 1 \\
Stores hand & 1 \\
Spannerman (Railway) & 1 \\
Driver (Bus) & 1 \\
Minor employee & 1 \\
Cocoa-estate labourer & 1 \\
Lawyer & 1 \\
Coffee-estate labourer & 1 \\
Salesman & 22 \\
Unspecified & 28 \\
\hline Children & 261 \\
\hline Total & \\
\hline
\end{tabular}

\section{Industrial Blindness (Table VI)}

From the ophthalmologists' point of view, industrial blindness is the most important aspect of the matter. Of our series of 261 cases, 106 ( 40 per cent.) had permanent and total loss of vision. The tea branch took the highest toll with 32 per cent., rock-blasting 23 per cent., and stone-cutting 15 per cent.-figures that are quite high if one accepts the proposition that almost all industrial accidents are preventable.

TABLE VI

CAUSES OF 106 CASES OF INDUSTRIAL BLINDNESS

\begin{tabular}{c|c|c|c}
\hline Cause & No. of Blind & $\begin{array}{c}\text { Percentage } \\
\text { of All Cases }\end{array}$ & $\begin{array}{c}\text { Percentage of all } \\
\text { Cases of Blindness }\end{array}$ \\
\hline Tea branch & 34 & 13 & 32 \\
Rock-blasting & 25 & 9 & 23 \\
Stone & 16 & 6 & 15 \\
Grass blade & 12 & $4 \cdot 6$ & $11 \cdot 3$ \\
Burn & 7 & $2 \cdot 6$ & $6 \cdot 6$ \\
Other Causes & 6 & $2 \cdot 2$ & $5 \cdot 6$ \\
\hline Accidents to Children & 6 & $5 \cdot 6$ \\
\hline
\end{tabular}

